\title{
SEISMED AND IDNDR: Opportunities to reduce the risk from earthquakes and other natural hazards
}

\begin{abstract}
SEISMED (Cooperative Project for Seismic Risk Reduction in the Mediterranean Region) and IDNDR (International Decade for Natural Disaster Reduction) are new programs designed to provide opportunities to reduce the risk from earthquakes and other natural hazards. The focus of SEISMED is on earthquakes in the Mediterranean region; whereas the focus of IDNDR is on eight natural hazards (earthquakes, severe storms, floods, landslides, volcanic eruptions, tsunamis, wildfires, and drought) throughout the world. The goal of both programs is to reduce risk in the urban centers through coordinated societal, scientific, and technical actions. Urban centers of the world will be made safer from natural hazards focusing on:

- Avoidance of the physical phenomena.

- Wise use of the land,

- Emergency preparedness and disaster recovery planning,

- Reduction of vulnerability,

- Adoption and enforcement of building and zoning regulations,

- Coordinated planning, design, and construction practices,

- Modification of the characteristics of ground shaking and ground failure, and

- Prediction and warning.
\end{abstract}

\section{Introduction}

\section{SEISMED}

SEISMED (Cooperative Project for Seismic Risk Reduction in the Mediterranean Region) was created in 1988 to cope with the earthquake hazard in the Mediterranean region. Fifteen countries: Albania, Algeria, Cyprus, Egypt, Greece, Israel, Italy, Libya, Malta, Monaco, Morocco, Spain, Tunisia, Turkey, and Yugoslavia, are participating in the project. The Mediterranean region, where approximately 350 million live, is characterized by a moderate to high level of seismicity (fig. 1) and several complex seismotectonic environments. Many devastating earthquakes have occurred in the region during recorded history. Locations of some of the most notable events during the 20 th century and areas of high potential are described below:

1. North Africa, where north-south convergence between the African and Eurasian tectonic plates is occurring. The Rif and Atlas Mountains and active thrust faults are evidence of the collision process. Three events, 1954 Orleansville, Algeria, 1960 Agadir. Morocco, and 1980 El Asnam. Algeria, claimed collectively more than 28,000 lives. injured thousands more, and caused economic losses that reached several billions of dollars.

2. Italy, where the complex tectonic history of the past 10 million years has been characterized by extension and accretion of new oceanic crust in the Tyrrhenian Sea west of Italy, uplift of the Apennines Mountains, crustal shortening across a 100 - to 200 $\mathrm{km}$-wide zone of the peninsula. and active subduction of the Ionian Sea beneath Calabria. Crustal extension began again approximately 4 million years ago in southern Calabria, 3 million years ago in Campania-Basilicata, and 2 million years ago in Abruzzo. One earthquake dominated the 20th century: the 1980 Campania-Basilicata earthquake, which left 3.114 dead, 7.675 injured, approximately 100,000 collapsed buildings, and economic losses that reached 15 to 20 billion dollars.

3. Jordan is an area of high risk, which is adjacent to the seismically active 1,000 -km-long Dead Sea rift zone, a left-lateral strike-slip fault system. Although very large earthquakes have occurred here in the past 2,000 years (for example, around 900 A.D.), no large events have occurred yet in the 20th century. In the broad region, active sea-floor spreading is taking place in the Red Sea and the Gulf of Aden and its extension in the Djibouti area of the Afar depression. The Dead Sea rift zone is a sinistral slip plate boundary that extends from the Gulf of Aqaba northeast along the Dead Sea-Jordan rift into central Lebanon, terminating in northwest Syria.

4. In Southern Europe, Greece, and Turkey, where approximately 15 percent of the total seismic energy released in the Mediterranean region each year is concentrated, the region is characterized by the North Anatolia fault, a 1.000 -km-long right-lateral strikeslip fault zone that cuts across Turkey. The most notable recent damaging earthquakes include: the 1963 Skopje. Yugoslavia earthquake, the 1966 earthquake in eastern Turkey, the 1970 Gadiz, Turkey earthquake. the 1977 Romanian earthquake, the 1979 Montenegro earthquake, and the 1981 Corinth and 1986 Kalamata, Greece earthquakes.

The goal of SEISMED is to foster actions that reduce the risk from the effects of earthquake ground shaking and ground failure in each country of the Mediterranean region. In order to reach this goal rapidly, SEISMED will provide specialists in each country with the best available information on: earthquake hazard assessment; vulnerability, loss, and risk assessments; and risk reduction.

With this basic information, individual countries and the region as a whole can devise, adopt, and enforce loss-reduction measures. 


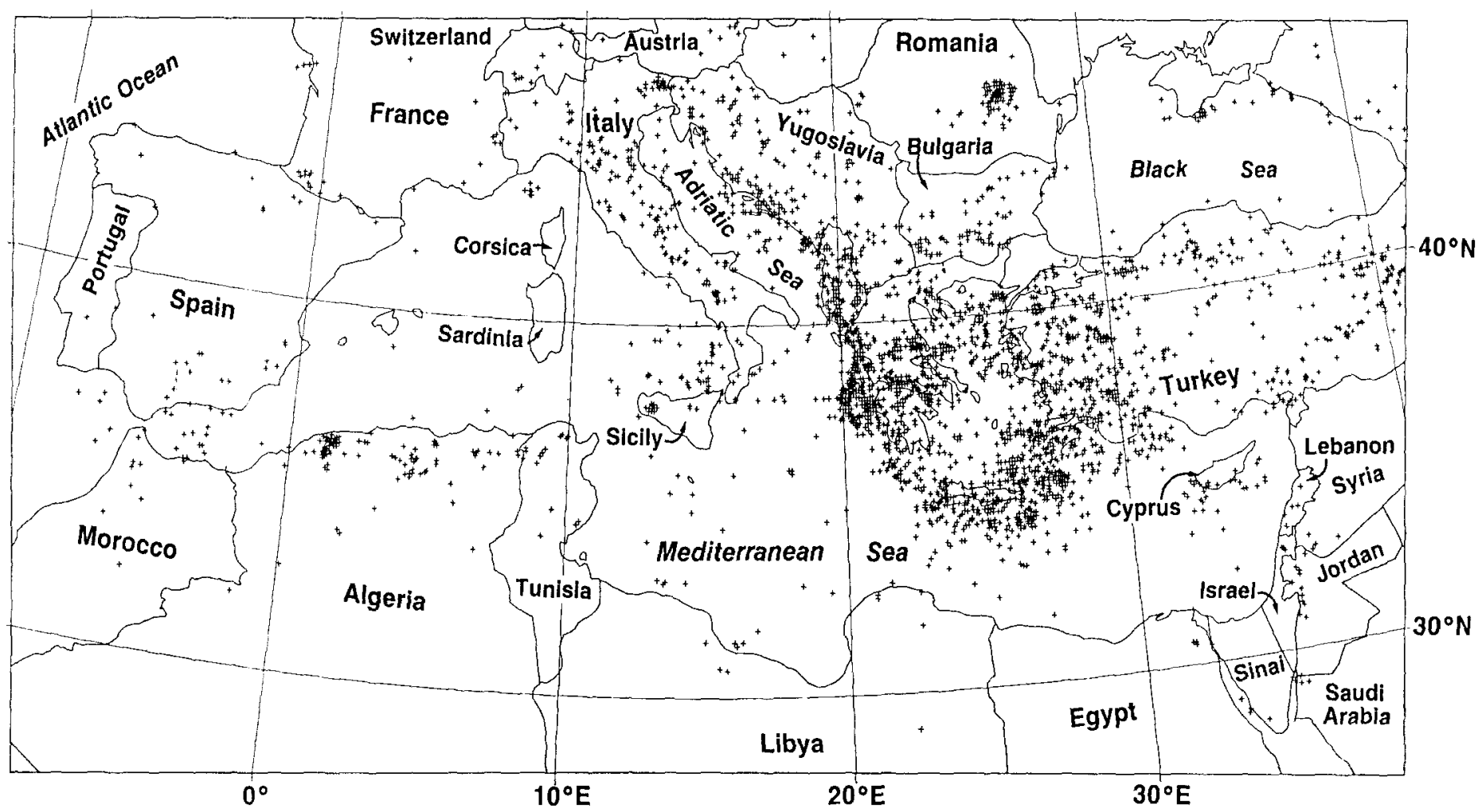

Figure 1.-Seismicity map of the Mediterranean region. Epicenters are for earthquakes having magnitudes of 5.0-5.9 in the period 1900-1988. (From U.S. Geological Survey's National Earthquake Information Center.)

\section{IDNDR}

The concept of the IDNDR was proposed in July 1984 by Dr. Frank Press, President of the U.S. National Academy of Sciences, at the Eighth World Conference on Earthquake Engineering. In 1987, the United Nations declared the period 1990-2000 to be an International Decade for Natural Disaster Reduction. Since then, the United States and at least 50 other nations and organizations have taken steps to organize and plan for concerted national and international actions during the $1990^{\circ}$ s to reduce the loss of life and economic losses from nitural hazards. On December 22, 1989, 155 nations accepted this goal at the 44th General Assembly of the United Nations (United Nations. 1989). They plan to forge unilateral, bilateral, and multilateral partnerships during the 1990's to make each country and the world safer from natural hazards.

Programs for the IDNDR will vary from country to country, but they are expected to include the following eight elements:

- hazard and risk assessments,

- prediction and warning of hazardous events.

- mitigation.

- preparedness for emergency response.

- preparedness for recovery and reconstruction,

- awareness and education.

- learning from disasters. and

- international collaboration.

These program elements will be implemented by each participating country for one or more of the following eight natural hazards: earthquakes, severe storms, floods, landslides, volcanic eruptions, tsunamis, wildfïres. and drought.

\section{Multidisciplinary roles in seismic risk reduction}

Geologists, seismologists, land-use planners, emergency managers, architects, and engineers will have important roles in SEISMED and IDNDR. Geologists and seismologists will contribute to the preparation of earthquake-hazard maps and their translation for use by land-use planners, emergency managers. architects, and engineers in loss-reduction measures.

Hazard maps typically require detailed research and technical studies that integrate geologic, geodetic, seismological, and geotechnical data on regional and urban scales (Hays, 1980). Each is described below.

1. Evaluation of seismic hasards on a regional scale: (a map scale of about $1: 100.000$ to $1: 1,250.000$ ). This part of a hazard assessment establishes the physical parameters of the region that are needed to evaluate the earthquake hazards of ground shaking, ground failure, surface-fault rupture, and tsunami runup. Technical tasks such as the following are required:

- Compilation of a catalog and map of the prehistorical, historical, and instrumental seismicity with case histories of the largest events.

- Performance of neotectonic studies (mapping, age dating. and trenching) to acquire information on earthquake-recurrence times in the past several thousand years not provided by historical or instrumental seismicity.

- Preparation of a seismotectonic map showing the location of active faults and seismogenic structures and their correlation with seismicity.

- Preparation of a map showing seismogenic zones and giving the magnitude of the maximum earthquake and the frequency of earthquake occurrence for each zone. 
- Preparation of a map showing tsunamigenic zones and their correlation with historical tsunamis.

- Preparation of slope-stability and liquefaction-potential maps.

- Specification of regional seismic wave attenuation laws and their uncertainty.

- Preparation of probabilistic ground-shaking-hazards maps in terms of peak bedrock acceleration and peak bedrock velocity for difference, exposure times, and probabilities of nonexceedance.

2. Evaluation of seismic hazard on an urban scale (that is, seismic zonation): (a map scale of about 1:5,000 to $1: 25,000$ ). This part of a hazard assessment integrates the seismotectonic and other physical data acquired in the regional study (Part 1 above) with site-specific data acquired in the urban area to produce groundshaking and ground-vulnerability maps. Technical tasks such as the following are required:

- Acquisition, synthesis, and integration of existing and new geologic, geophysical, and geotechnical data to characterize the soil/rock columns in terms of their physical properties and their response to various levels of ground shaking.

- Preparation of ground-shaking-hazard maps showing the dynamic amplification factors for soil/rock columns in terms of amplitude and frequency composition of ground shaking and the level of dynamic shear strain for a range of seismic loads.

- Preparation of maps showing the potential for surface-fault rupture and tsunami inundation.

- Preparation of a map showing the potential for liquefaction.

- Preparation of a map showing the potential for seismicallyinduced landslides.
- Preparation of a map that synthesizes the ground-shaking, ground-failure, and inundation hazards.

With these maps, urban centers (fig. 2) can take societal, scientific, and technical actions to reduce the earthquake risk to existing and new development. The key strategies include: avoidance of the physical phenomena; wise use of the land: emergency preparedness and disaster recovery planning; reduction of vulnerability; adoption and enforcement of building and zoning regulations; coordinated planning, design. and construction practices; modification of the characteristics of ground shaking and ground failure; and prediction and warning. Each of these applications is discussed in the following sections.

Avoidance.-The least expensive and most logical strategy is avoidance. Planners should take the lead in identifying those locations in an urban center that are most susceptible to physical effects such as ground shaking, ground failure, surface-fault rupture, and tsunami runup, and they should promote physical planning practices that avoid these hazards. Whenever possible, for example, physical plans should avoid locating buildings and lifeline systems on soils that have the same resonant period of vibration as the building or lifeline system; in configurations where they will hammer or pound adjacent structures; on unstable soils susceptible to liquefaction. landslides, and debris flows; and in locations subject to surface fault rupture, and flooding from tsunami runup, or a dam failure.

Wise Use of the Land. - The goal of earthquake risk reduction is to reduce the destructiveness and societal impacts of future earthquakes by enforcing loss-reduction strategies adopted by local government. Destructiveness is primarily related to three factors: (1) the magnitude or energy release of the earthquake, (2) the proximity of

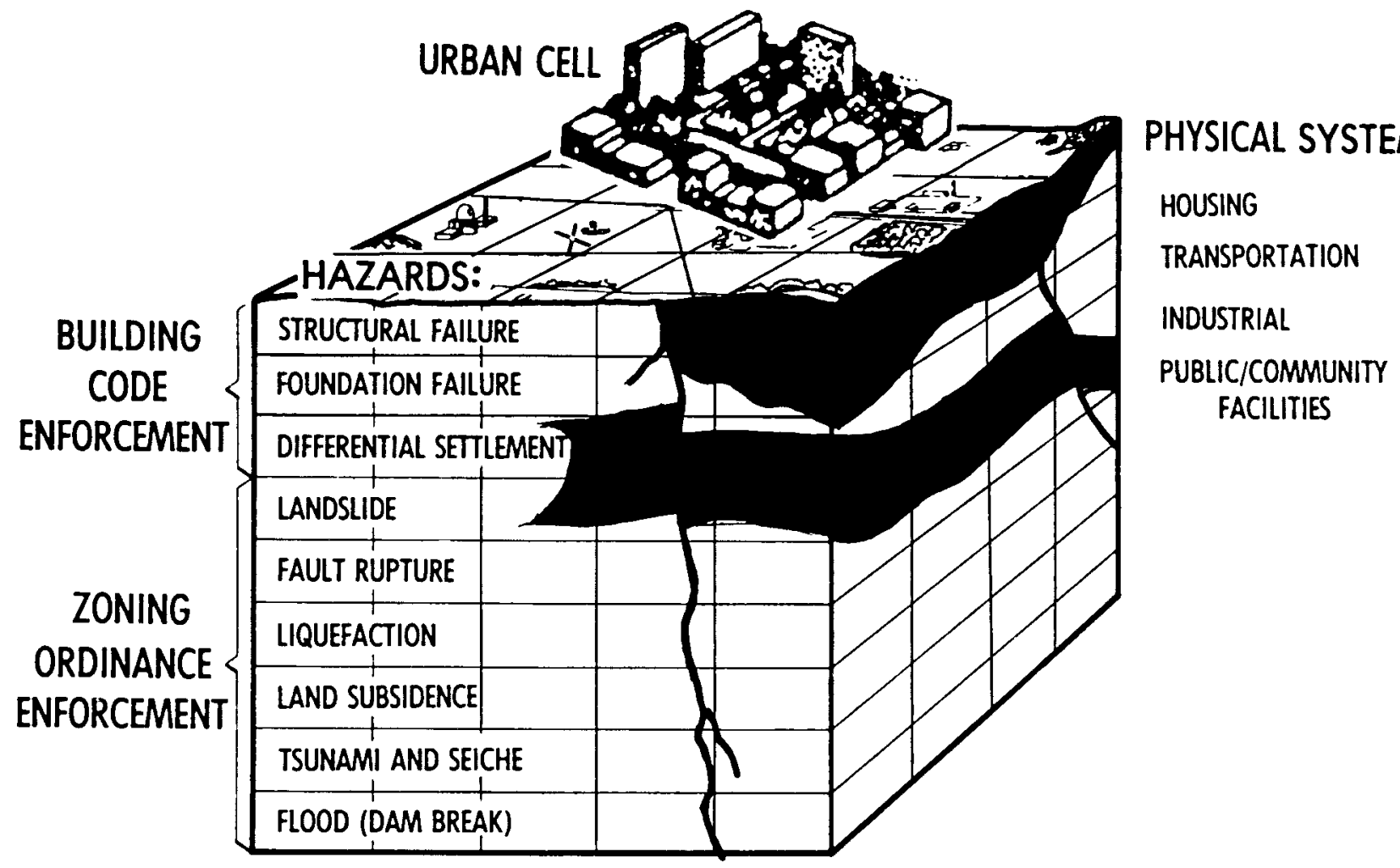

Figure 2.-Urban centers, shown schematically here, have societal, scientific, and technical options available for reducing the earthquake risk to existing and new development. 
the earthquake source to the urban center, and (3) the extent to which wise land-use planning options have been implemented in the urban center to mitigate the effects of ground shaking, ground failure, surface-fault rupture, and tsunami runup when the earthquake strikes. Past earthquakes have taught planners many important lessons (Earthquake Engineering Research Institute, 1986, 1989a, 1989b; State of California, 1990) that can now be incorporated into planning options for wiser use of the land. The primary lessons and planning options are:

- Lesson. - Expect earthquakes to recur where they occurred in the past in response to the seismic cycle of stress build up and stress release of active faults and seismogenic structures in the region.

Planning option. - The type and density of each use should correlate with the hazard. Knowledge of what happened in the past must be used as a guide of what to expect in the future.

- Lesson. - Expect a $16 \mathrm{~km}$ or longer fault in most parts of the world to generate a magnitude 6 or greater earthquake. Such earthquakes can generate severe ground shaking and trigger extensive ground failure over a broad area.

Planning option. - To the extent possible, map the location of active faults and plan new urban development in terms of the potential threat from each one, paying special attention to those that are $16 \mathrm{~km}$ or longer.

- Lesson. - Expect the length, width, rupture history, and fault type of an active fault zone or seismogenic structure and changes in thickness, physical properties, and geometry of the soil column of that zone or structure to control the main features of the amplitude, spectral compositions, and duration of ground shaking.

Planning option. - Use knowledge of the location and physical parameters of the active faults and seismogenic structures and the characteristics of the soil column in the region and urban center as a guide for siting, designing, and constructing buildings and lifeline systems.

- Lesson.-Expect water-saturated, unconsolidated, sandy soils to liquefy and unstable slopes to fail when shaken in an earthquake. Planning option. - Use knowledge of the ground-failure potential as a guide for siting, designing, and constructing buildings and lifeline systems.

- Lesson.-Expect buildings and lifeline systems sited above ground (for example, bridges) to be more vulnerable to ground shaking and buried lifeline systems (for example, buried pipelines, tunnels, and underground mass transit systems) to be more vulnerable to ground failure.

Planning option. - Use technical judgment when siting and designing buildings and lifeline systems to minimize the problems associated with ground shaking and ground failure.

- Lesson. - Expect short, stiff buildings and stiff bridges to be more vulnerable than tall, flexible buildings and long, linear lifeline systems to short-period vibrations (for example, ground motion accelerations characterized by periods less than 0.5 seconds).

Planning option.--Whenever possible, locate short, stiff buildings and stiff bridges in locations that are not expected to experience high levels of ground acceleration (that is, at least $40 \mathrm{~km}$ from the potential causative fault on deep, soft soils), especially if the fault is capable of generating magnitude 6 or greater earthquakes. In all cases, take the appropriate steps to ensure that the design levels will ensure an adequate margin of safety.

- Lesson. - Expect tall, flexible buildings and long, linear lifeline systems to be more vulnerable than short. stiff buildings and bridges to long duration, long-period vibration (for example, ground motion velocities and displacements characterized by periods greater than 0.5 seconds).

Planning option. - Whenever possible, locate tall, flexible buildings and long, linear lifeline systems at locations that are not expected to experience high levels of long-duration ground veloc- ity and ground displacement (that is, within about $40 \mathrm{~km}$ of the potential causative fault on firm soil). In all cases, take appropriate steps to ensure that the design levels will ensure an adequate margin of safety, especially for soft soil sites (Earthquake Engineering Research Institute, 1989a; State of California, 1990).

- Lesson. - Expect the potential for damage to be greater than normal when the natural periods of vibration of the soil column and the building are closely matched.

Planning Option. - Whenever possible, site short, stiff buildings and bridges on soil columns having long periods of vibration and tall, flexible buildings and long, linear lifeline systems on soil columns having short periods of vibration and uniform geometry. In all cases, take appropriate steps to ensure that the design levels will ensure a margin of safety in the period band where resonance is expected.

Emergency Preparedness and Disaster Recovery Planning. - The emergency manager needs the best available maps of the earthquake effects to develop realistic scenarios of what to expect and what to do in a damaging earthquake (Der Heide, 1989). These scenarios are the technical basis for emergency-response plans and, in the case of a disaster that overwhelms the response capability of the community, disaster-recovery plans. From past earthquakes, emergency managers have learned that a damaging earthquake will not only expose all of the flaws in the siting, design, and construction of buildings and lifeline systems in the urban center but will also exhibit all of the weak elements of the emergency-response plans. Consequently, emergency managers should develop response plans based on the following assumptions:

- The earthquake will strike without warning at the "worst" time of the day and season of the year.

- Physical effects observed in past earthquakes, which have the same magnitude and location as the scenario earthquake, will be repeated. (Note: Case histories of past earthquakes should be studied in detail to define the range of response needs.)

- Ground shaking and ground failure will cause the greatest damage, social impacts, and loses. Fire, flooding from dam breaks or debris dams, and aftershocks will complicate the emergency response.

- The oldest and most densely populated parts of the urban center will suffer the greatest damage, highest losses, and the greatest number of casualties and injuries. The poor and elderly will be severely impacted. Homelessness will be a major problem.

- The short-term physical, emotional, and social impacts on the populace will be varied and complex. Families will be separated, people will be trapped in collapsed buildings and highway structures, and huge traffic jams will be typical.

- Movement into and away from damaged areas will be hampered for days to weeks due to debris, damaged transportation systems, and ongoing search and rescue operations.

- Communications will be disrupted for hours to weeks with some communities being isolated for weeks. Coordination within and between organizations should be expected to be weak.

Disaster-recovery planning should be based on the following assumptions:

- The political pressures for restoration of services will be very great because of the desire to restore the urban center to normal as quickly as possible.

- Assessment of damage will be a top priority, but experienced people to make the assessments will be in short supply.

- Inspection and posting of "red" (unsafe, do not enter), "yellow" (caution in entering), and "green" (safe to enter) tags on buildings will be a critically important task charged with emotion and political pressures.

- Removal of debris will be an urgent, complicated task, especially while search and rescue operations are underway. 
- Rebuilding to improve the seismic safety of the urban center will be a political problem; therefore, improved building and zoning regulations should be devised and adopted in advance, if possible.

Reduction of Vulnerability. - Large cities and, in some cases, the capitals of many countries in the Mediterranean region are located in zones of moderate to high seismicity. Damage and loss of function in a large city or capital city would be very disruptive to the country and the region. The capital is usually the headquarters or center for decisionmaking; political, administrative, and cultural leadership; the army; banks, insurers, and developers; the political party or parties; newspapers, radio, and television; and foreign embassies. Planners, architects, and engineers can reduce the vulnerability of existing development by application of structural and nonstructural measures in selected parts of the urban center (Earthquake Research Institute, $1989 \mathrm{c})$. In the use of hazard maps to identify the areas expected to experience severe ground shaking, ground failure, surface-fault rupture, or tsunami runup, the priorities should be:

- Strengthen essential facilities (that is, those facilities that must remain functional during and after an earthquake). Relocate or replace those facilities for which seismic safety standards cannot be met.

- Strengthen high-occupancy facilities that are deficient and reduce occupancy in substandard buildings.

- Strengthen hazardous buildings that have a high probability of collapse. Demolish those buildings that cannot be economically strengthened to retrofit standards. Develop evacuation plans for each hazardous building.

- Reinforce buildings and storage tanks that could rupture and release hazardous materials during an earthquake.

- Correct nonstructural problems in buildings and facilities.

Adoption and Enforcement of Building and Zoning Regulations. - Planners, architects, and engineers have an important role in the adoption and enforcement of building and zoning regulations. Experience in past earthquakes has shown that economic loss. loss of life, and injuries are lower in countries that: adopt and enforce seismic design provisions through a building code, a legal document requiring a minimum design standard (the goal should be life safety - that is, to prevent collapse but to allow damage of the building in a major earthquake); and control the types and density of land use in areas prone to strong ground shaking and ground failure through zoning ordinances.

Coordinated Planning, Design, and Construction Practices.-Planners, architects, and engineers have learned from earthquakes throughout the world that physical planning practices must be integrated with design and construction practices if buildings and lifeline systems are to withstand the physical effects of ground shaking and ground failure with a high degree of reliability. The most important lessons and planning-design-construction options include the following:

- Lesson. - Severe damage, which is allowed for major earthquakes (in the philosophy of the building code), should be expected in any earthquake when any one of the three critical parameters-amplitude, spectral composition, and duration. of strong ground shaking - are underestimated in design.

Planning, design, and construction options. - Select design parameters that ensure an adequate margin of safety against collapse and minimize damage by focusing primarily on the fault (for example, length, rupture, history, history of activity, location, and maximum magnitude, and the soil column under the building (for example, thickness, softness, geometry). These physical parameters control the amplitude, spectral composition, and duration of ground shaking.
- Lesson.--Damage from ground failure induced by ground shaking should be expected when the geotechnical properties of the foundation materials indicate instabilities.

Planning, design, and construction options. - Abandon construction sites having high potential for permanent displacement caused by liquefaction. landslides, or differential settlements. Plan lower risk uses for these sites (for example, parks, open space).

- Lesson. - Expect asymmetrical, irregular, and very long buildings to perform poorly in an earthquake, and their construction to make the overall community more vulnerable.

Planning, design, and construction options. - Create physical plans that eliminate or minimize the use of asymmetrical, irregular, and very long buildings.

- Lesson.-Damage should be expected in buildings and lifeline systems having lateral-force-resisting systems that are not seismically resistant (for example, unreinforced masonry, reinforced concrete with masonry infill walls, brittle concrete columns).

Planning, design, and construction options. - Plan for compatible building materials that are designed and constructed to be horizontally and vertically homogeneous and continuous in mass. stiffness, and strength.

- Lesson. - Damage should be expected when connections and detailing are poor or lacking.

Planning, design, and construction options. - Quality of construction and attention to construction details will compensate for uncertainties encountered in siting and design.

Modification of the Characteristics of Ground Shaking and Ground Failure.-Planners, architects, and engineers should work together to resolve problems associated with important new or existing civic, historical, or cultural buildings determined to be vulnerable to ground shaking or ground failure. For example, the urban center can use: base isolation technology (Earthquake Engineering Research Institute, 1990) to reduce ground shaking levels, or engineering methods to dewater a site prone to liquefaction or to stabilize slopes prone to landslides (Schuster and Krizek, 1978).

Prediction and Warning.-Planners and emergency managers should collaborate with scientists who are working to predict the time, place, magnitude, and probability of occurrence of damaging earthquakes. At the present, because the science of earthquake prediction is young, only intermediate and long-term forecasts are feasible (that is, a few years to a few decades) (Simpson and Richards. 1981). Reliable short-term predictions are likely in a few selected areas in the 1990 's. Planners and emergency managers should utilize the information contained in warnings associated with intermediate and long-term predictions to improve physical plans and emergencyresponse and disaster-recovery plans of the urban center.

\section{Conclusions}

Countries of the Mediterranean region have new opportunities provided by SEISMED and IDNDR to reduce their risk from earthquakes. Each country has buildings and lifeline systems that are potentially vulnerable to ground shaking. ground failure. surfacefault rupture, and, in some cases, tsunami runup. Some country capitals are also potentially vulnerable. Geologists, seismologists. planners, emergency managers, architects. and engineers have important roles in devising and implementing societal, scientific. and technical actions that will reduce the risk from the these earthquake hazards. 


\section{References}

Der Heide, Erik, A., 1989, Disaster Response, Principles of Preparation and Coordination: St. Louis, MO, C.V. Mosby Company, 363 p.

Earthquake Engineering Research Institute, 1986, Reducing Earthquake Hazards: Lessons Learned From Earthquakes: Publication No. 86-02, El Cerrito, California, 208 p.

-1989a, Lessons Learned From the 1985 Mexico Earthquake: Publication No. 89-02, El Cerrito, California, 264 p.

-1989b, Armenia Earthquake Reconnaissance Report, Earthquake Spectra, v. 5 Special Supplement, 175 p.

1989c, The Basics of Seismic Risk Analyses, Earthquake Spectra, v. 5 , p. $675-702$.

1990, Base Isolation, Earthquake Spectra, v. 6, 322 p

Hays, Walter, W., 1980, Procedures for Estimating Earthquake Ground Motions: U.S. Geological Survey Professional Paper P-1114, 77 p.

Schuster, Robert L. and Krizek, Raymond J. ed., 1978, Landslides, Analysis and Control, Transportation Research Board, Special Report 176: Washington, D.C., National Academy of Sciences, 234 p.

Simpson, David W. and Richard, Paul G., ed., 1981, Earthquake Prediction, An International Review: Washington, D.C., American Geophysical Union, Maurice Ewing Series 4, 680 p.

State of California, 1990, Competing Against Time, Report to Governor George Deukmejiam from the Governor's Board of Inquiry on the 1989 Loma Prieta Earthquake, North Highlands, California, 264 p.

United Nations, 1989. International Decade for Natural Disaster Reduction, 44th Session of the General Assembly, Resolution 44/236, 6 p. $\square$

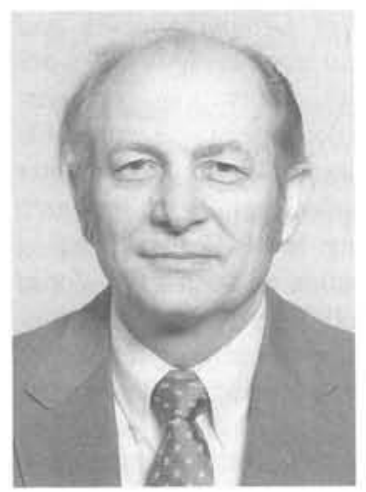

Dr. Walter W. Hays is Deputy Chief for Research Applications in the U.S. Geological Survey's Office of Earthquakes, Volcanoes, and Engineering. Since 1977, and after 16 years as an educator and a research engineering seismologist, he has been responsible for fostering research applications and loss reduction throughout the United States. On behalf of Unesco and UNDRO, he participated in earthquake engineering programs in Algeria and Jordan and in the Mediterranean region. Through USGS's international activities, he contributed to scientific programs in Spain, Italy, Japan, China, Argentina, Switzerland, Australia, and the Soviet Union. He participated in the formative phases of the International Decade for Natural Disaster Reduction. $\mathrm{He}$ is also a former director of the Earthquake Engineering Research Institute. Dr. Hays has published more than 100 papers, books, and reports.

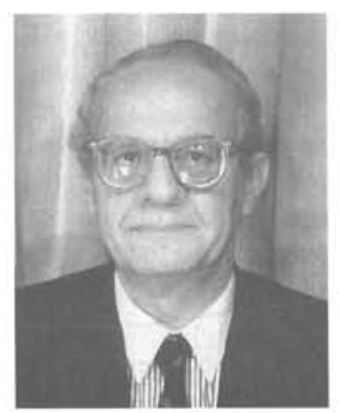

Dr. Ludovic van Essche, a South African, was born on July 13, 1935, in Brussels, Belgium, and was educated in South Africa and Great Britain (Architecture at UCT and Town Planning at the Architectural Association, London). He has been in private practice in Cape Town and London, and he has lectured and done research on housing and urbanization in developing countries at universities in Lund, Liverpool, and Nairobi, and at the Royal Academy in Copenhagen. From 1970 to the present he has held positions in the United $\mathrm{Na}$ tions, first in New York (Center for Housing Building and Planning) involved in technical cooperation in housing and urban planning, and now in the Office of the United $\mathrm{Na}$ tions Disaster Relief Coordinator (UNDRO), Geneva, involved in disaster mitigation in seismic regions. $\mathrm{He}$ is presently Senior Officer and Deputy Chief of the Disaster Mitigation Branch, UNDRO. He has published papers on urban upgrading in developing countries, land-use aspects, sanitation aspects, and legal aspects of disaster mitigalion (19761979); shelter after disaster (1982); and a disaster mitigation manual (1991).

Dr. Franco Maranzano was educated in geology at the University of Rome and did postgraduate studies at Imperial College of London. He was involved with seismology and applied geophysics at the Geophysical Observatory of Trieste, in Australia, at Imperial College, and in Nigeria. He participated in United Nations projects in Solomon Islands, Chile, and Costa Rica working on geology, seismotectonic settings, geophysics, and natural resources. He has been involved in the evaluation of projects and markets in Europe, Africa, and the Middle East for US Steel Corporation. And he has been a consultant in natural resources, the environment, and management in several countries for a variety of companies, organizations, and governments. He is now in charge of SEISMED. 